\title{
Effects of Mulch Types and Concentrations of 1,3-Dichloropropene plus Chloropicrin on Fumigant Retention and Nutsedge Control
}

\author{
Bielinski M. Santos, James P. Gilreath, Timothy N. Motis, \\ Marcel von Hulten, and Myriam N. Siham ${ }^{1}$
}

\begin{abstract}
AdDitionAl INDEX wORDs. Cyperus rotundus, methyl bromide, Inline, virtually impermeable film, metalized mulch, soilborne pests

SUMMARY. Field trials were conducted to: 1$)$ determine the effect of mulch types and applied concentrations of 1,3-dichloropropene + chloropicrin (1,3-D + Pic) on fumigant retention; and 2 ) examine the influence of mulch films and $1,3-\mathrm{D}+$ Pic concentrations on purple nutsedge (Cyperus rotundus) control. 1,3-D + Pic concentrations were $0,600,1000$, and $1400 \mathrm{ppm}$, and mulch types were white on black high-density polyethylene mulch (HDPE), white on black virtually impermeable film (VIF-WB), silver on white metalized mulch, and green VIF (VIF-G). Regardless of the initial 1,3-D + Pic concentrations and mulch types, fumigant retention exponentially decreased over time. When $1400 \mathrm{ppm}$ of $1,3-\mathrm{D}$ + Pic were injected into the soil, 1,3-D + Pic dissipation reached $200 \mathrm{ppm}$ at 3.2, 2.9, 2.2, and 1.5 days after treatment (DAT) under VIF-G, VIF-WB, metalized, and HDPE mulches, respectively. At 5 weeks after treatment (WAT), HDPE mulch had the highest purple nutsedge densities among all films. The treatments covered with VIF-G had purple nutsedge densities $<5$ plants $/ \mathrm{ft}^{2}$, regardless of the applied fumigant concentration, while VIF-WB and metalized mulch reached this weed density with $696 \mathrm{ppm}$ of the fumigant. In contrast, $1186 \mathrm{ppm}$ of 1,3$\mathrm{D}+$ Pic were needed to reach this weed density with HDPE mulch. Correlation analysis showed that mulch fumigant retention readings at $3 \mathrm{DAT}$ effectively predict purple nutsedge densities at 5 WAT $(r \leq-0.94)$. These findings proved that 1,3-D + Pic activity on purple nutsedge can be improved with the use of more retentive films, which cause longer fumigant retention, thus improving efficacy. Growers might elect reducing 1,3-D + Pic rates to compensate for the relatively higher cost of fumigant-retentive mulches, without losing herbicidal activity.
\end{abstract}

$\mathrm{I}$ n the U.S., strawberry (Fragaria xananassa), tomato (Lycopersicon esculentum), bell pepper (Capsicum annuum), cucumber (Cucumis sativus), squash (Cucurbita pepo), and watermelon (Citrullus lanatus) produce an annual gross value of approximately $\$ 4.1$ billion (U.S. Department of Agriculture, 2005). In 2004, Florida produced more than $25 \%$ of the total U.S. sales of these six commodities, with the majority of the planted area being fumigated during the last two decades with methyl bromide $(\mathrm{MBr})$ to control most soilborne pests (U.S. Department of Agriculture, 2005 ). However, MBr is being phased out in compliance with the Montreal Protocol, which classifies this fumigant as an ozone-depleting molecule (U.S.

${ }^{1}$ Assistant Professor of Horticulture, Professor of Weed Science, former Research Associate, and former Research Assistants, respectively, Gulf Coast Research and Education Center, University of Florida, Wimauma, FL 33598; email: bmsantos@ufl.edu
Environmental Protection Agency, 1999; Watson et al., 1992).

Currently, one of the main alternatives to replace $\mathrm{MBr}$ is the combination of the nematicide 1,3-D and the fungicide Pic, which can be either injected into the soil with chisels or applied through drip irrigation lines. Previous studies have shown that although soilborne fungi and nematodes can be effectively managed with $1,3-\mathrm{D}+\mathrm{Pic}$, this fumigant does not consistently control purple nutsedge and yellow nutsedge (Cyperusesculentus) (Gilreath and Santos, 2004a). These weeds have the ability to penetrate the mulch with their sharp leaf tips. Ample information exists on nutsedge interference with vegetable crops. Motis et al. (2003) found that a nutsedge density of 90 plants $/ \mathrm{m}^{2}$ reduced bell pepper yield by at least $70 \%$, whereas Gilreath and Santos (2004b) showed that tomato yield loss from season-long purple nutsedge interference could reach $51 \%$ with a density of 105 plants $/ \mathrm{m}^{2}$. Morales-Payan et al. (1997) demonstrated that a density of 50 plants $/ \mathrm{m}^{2}$ of purple nutsedge reduced bell pepper and tomato yield by $<10 \%$. These weed densities are common in Florida warm weather. The addition of preemergence herbicides has been a tool to control many noxious weeds in polyethylenemulched crops. Halosulfuron and metolachlor have shown acceptable activity mainly against nutsedges, but these herbicides are not labeled for application in all crops (Stall and Gilreath, 2002). Additionally, herbicide applications prior to fumigation increases production costs and the risk of personnel exposure.

Most high-value vegetable crops are grown with drip irrigation on beds covered with HDPE mulch, which has limited retention of fumigant vapors. In sandy soils, the emusifiable formulation of $1,3-D+$ Pic is usually applied at rates between 13 and $56 \mathrm{gal} / \mathrm{acre}$ in broadcast applications, and typical dilution rates are between 500 and 1500 ppm (Dow AgroSciences, 2006). Previous studies proposed that fumigant activity against soilborne pests can be enhanced by using highly-retentive mulches, such as VIF, which could increase duration under the mulch of relatively high fumigant concentrations, consequently allowing more time for exposing soilborne pests to lethal rates and for lateral distribution in the soil (Gilreath et al., 2005; Minuto et al. 1999; Santos et al., 2005). Desaeger et al. (2004) showed that 1,3-D + Pic vapors cause significant soilborne pest

\begin{tabular}{llll}
\hline $\begin{array}{l}\text { Units } \\
\text { To convert U.S. to SI, } \\
\text { multiply by }\end{array}$ & U.S. unit & SI unit & $\begin{array}{l}\text { To convert SI to U.S., } \\
\text { multiply by }\end{array}$ \\
\hline 0.3048 & $\mathrm{ft}$ & $\mathrm{m}$ & 3.2808 \\
0.0929 & $\mathrm{ft}^{2}$ & $\mathrm{~m}^{2}$ & 10.7639 \\
3.7854 & $\mathrm{gal}$ & $\mathrm{L}$ & 0.2642 \\
9.3540 & $\mathrm{gal} / \mathrm{acre}$ & $\mathrm{L} \cdot \mathrm{ha}^{-1}$ & 0.1069 \\
2.54 & $\mathrm{inch}(\mathrm{es})$ & $\mathrm{cm}$ & 0.3937 \\
0.4536 & $\mathrm{lb}$ & $\mathrm{kg}$ & 2.2046 \\
0.0254 & $\mathrm{mil}$ & $\mathrm{mm}$ & 39.3701 \\
1 & $\mathrm{ppm}$ & $\mu \mathrm{L} \cdot \mathrm{L}^{-1}$ & 1
\end{tabular}


control beyond wetted fronts. Soil texture plays a significant role in fumigant distribution throughout planting beds. However, fumigant lateral movement is limited in Florida spodosols, resulting in rapid volatilization through the mulch and hence poor nutsedge control on bed shoulders (Desaeger et al., 2004; Gilreath et al., 2003). Therefore, increased fumigant retention needs to be addressed to improve weed control efficacy.

One of the advantages of drip-application of 1,3-D + Pic is that it reduces production costs by relying on the same drip irrigation lines that are used for irrigation and fertilization. Thus, it is necessary to determine the potential use of this application method on fumigant retention and weed control in mulched-vegetable crops. Therefore, the objectives of this study were to 1 ) determine the effect of mulch types and applied concentrations of 1,3-D + Pic on fumigant retention; and 2) examine the influence of mulch films and $1,3-\mathrm{D}+$ Pic concentrations on purple nutsedge control.

\section{Materials and methods}

Two field trials were conducted during Fall 2003 and Spring 2004 at the GulfCoast Research and Education Center of the University of Florida in Bradenton. The soil was classified as EauGallie fine sand (Alfic Haplaquod, sandy, siliceous, hyperthermic) with $1.0 \%$ organic matter and $\mathrm{pH}$ 6.7. Selected fields were infested with purple nutsedge at a density of approximately 15 plants $/ \mathrm{ft}^{2}$. Different fields were used for each season. Treatments were distributed in a split-plot design with five replications. 1,3-D + Pic concentrations $(0,600,1000$, and 1400 ppm) were the main plots, whereas mulch types were the subplots. Mulch types were 1) white on black HDPE mulch (1.25 mil thick; Pliant Corp., Schaumburg, Ill.); 2) white on black VIF (3 mil thick; Industrial Plastica Monregalise, Mondovi, Italy); 3 ) silver on white metalized mulch ( 3 mil thick; Pliant Corp., Schaumburg, Ill.); and 4) green VIF (3 mil thick; Klerk's Plastic, Hoogstraten, Belgium). The fumigant concentrations were chosen based on their activity against nutsedge in preliminary tests, and achieved by mixing $0,136,226$, and $317 \mathrm{lb}$ of $1,3-\mathrm{D}+$ $P$ ic in a delivery volume of 1 acre-inch of water per applied acre $(27,154 \mathrm{gal}$ water per applied acre).
Planting beds were 32 inches wide at the base, 28 inches wide at the top, 8 inches high, and spaced 60 inches apart on centers. Each experimental unit comprised a 15 -ft-long bed. Immediately after bed pressing, two drip irrigation lines (T-Tape; T-Systems International, San Diego) with emitters every 12 inches were placed 12 inches apart and centered on bed tops, and beds were covered with their respective mulches. Irrigation flow was approximately $0.40 \mathrm{gal} / 100 \mathrm{ft} / \mathrm{min}$.

Soil air under plastic mulch was sampled at bed centers using a Gastec Model GV-100 gas sampling pump, equipped with trichloroethylene detection tubes ( $5 \%$ accuracy; Gastec Corp., Ayase-City, Japan), which detected concentrations of 1,3-D at $1,2,3$, and 4 DAT (Gastec Corp., 2003). This measurement reflects fumigant retention under the films (Desaeger et al., 2004). Purple nutsedge population densities were determined at 2 and 5 WAT by counting emerged plants within each experimental unit. Data were analyzed with the general linear model procedure to determine interactions between the two factors and regression analysis was applied to characterize the effect of time after $1,3-D+$ Pic application on mulch fumigant retention, and between applied 1,3-D + Pic concentration and purple nutsedge densities (SAS, 2000). Orthogonal contrasts were used to compare specific treatment means and Pearson correlation was utilized to determine the association between purple nutsedge densities at 5 WAT and $1,3-\mathrm{D}+$ Pic retention in the soil at 3 DAT (SAS, 2000).

\section{Results and discussion}

The interaction between treatments and seasons was nonsignificant. Concentrations of 1,3-D + Pic and mulch types interactively influenced fumigant retention. Regardless of the initial 1,3-D + Pic concentrations and mulch types, fumigant retention exponentially decreased over time (Fig. $1 \mathrm{~A}-\mathrm{C}$ ). At $\mathrm{l}$ and 2 DAT, VIF-G had the highest fumigant retention among all mulches, while differences in retention among mulches tended to disappear as time after application approached the fourth day.

When $600 \mathrm{ppm}$ of $1,3-\mathrm{D}+$ Pic were injected into the soil, the regression equations indicated that at 1 DAT, VIF-G retained 3.3 times (34l ppm) more fumigant than under HDPE mulch (102 ppm). Similarly, at the same sampling time, VIF-WB and metalized mulch had 269 and 249 ppm, respectively (Fig. 1A). A similar tendency persisted during the second day after fumigant injection, when all mulches had $\leq 200 \mathrm{ppm}$ of 1,3-D + Pic. Based on the predicted values of each regression equation, a concentration of $200 \mathrm{ppm}$ of 1,3-D + Pic would be reached at 1.9, 1.4, and 1.2 DAT with VIF-G, VIF-WB, and metalized mulch, respectively. In contrast, it would require $0.6 \mathrm{~d}$ reaching that soil concentration with HDPE mulch, which suggested that within the first $48 \mathrm{~h}$ after application, these highly retentive films retained between two and three times more fumigant than HDPE mulch when the initial fumigant concentration was $600 \mathrm{ppm}$.

As the injected concentration of the fumigant increased to $1000 \mathrm{ppm}$, retention differences among mulches were more evident at 1 DAT, with VIF-G, VIF-WB, and metalized mulch maintaining 2.5, 2.1, and 1.8 times more 1,3-D + Pic than with HDPE mulch (Fig. 1B). A similar situation occurred at 2 DAT. However, at 3 DAT, the soil under all mulches had $\leq 200$ ppm, with no significant retention differences between VIF-G and VIF-WB, and between the metalized and HDPE mulches. It took 2.7, 2.3, 1.8, and 1.1 DAT to reach a concentration of 200 ppm in the plots covered with VIF-G, VIF-WB, and metalized, and HDPE mulches, respectively, demonstrating the high fumigant retention properties of the first three films.

When the fumigant was applied at $1400 \mathrm{ppm}, 1,3-\mathrm{D}$ + Pic dissipation reached $200 \mathrm{ppm}$ at $3.2,2.9,2.2$, and 1.5 DAT under VIF-G, VIF-WB, and metalized, and HDPE mulches, respectively (Fig. 1C). During the first 2 DAT, there were significant differences among each mulch type, when HDPE mulch had the lowest concentration. However, at 3 DAT, there were no differences between VIF-G and VIF-WB, and between metalized and HDPE mulches, whereas at 4 DAT the 1,3-D + Pic soil concentrations were the same regardless of films.

With regard to purple nutsedge densities, there were significant interactions between mulch types and $1,3-\mathrm{D}+$ Pic concentrations at 2 and 5 WAT. Linear regression equations characterized the response of weed populations to 


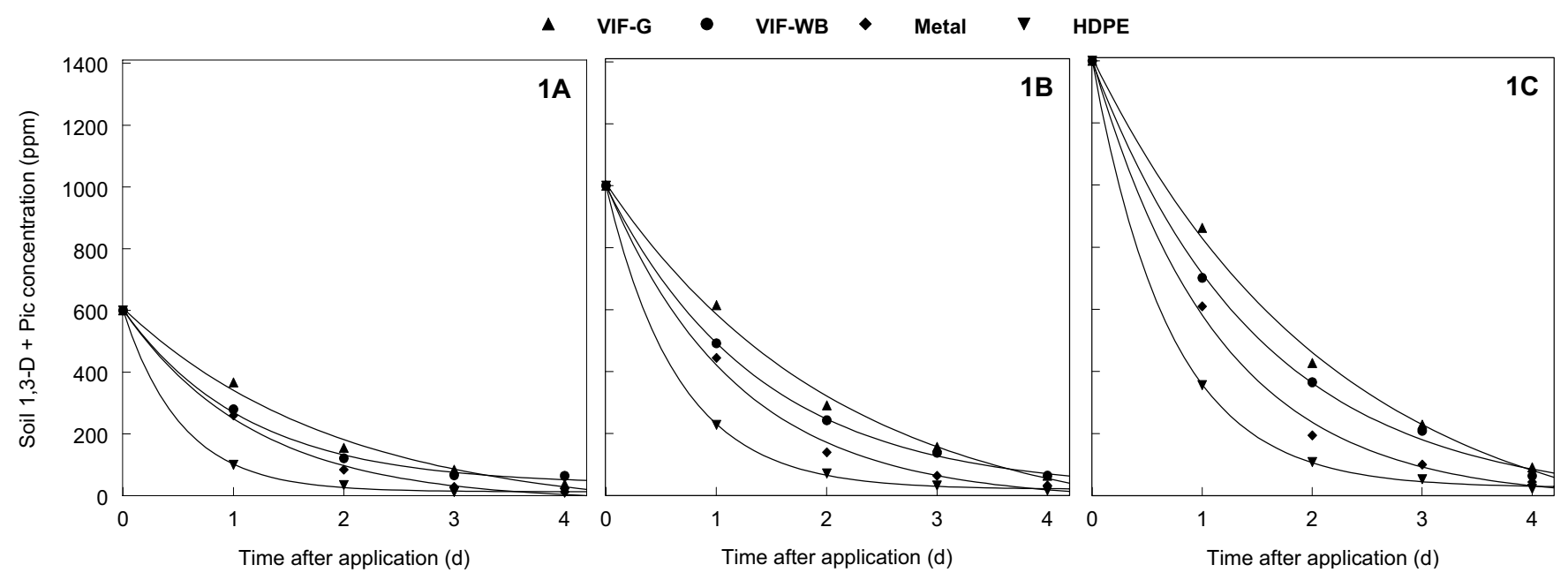

Fig. 1. Effects of the application of (A) 600, (B) 1000, and (C) $1400 \mathrm{ppm}$ of 1,3-dichloropropene + chloropicrin (1,3-D + Pic) under different mulch types on soil 1,3-D + Pic concentration at varying times after application. Mulch films are green virtually impermeable film (VIF-G), white on black VIF (VIF-WB), metalized (metal), and high-density polyethylene (HDPE) mulches. Regression equations are: $\mathrm{y}=-\mathbf{5 7 . 6}+664.3 \mathrm{e}^{(-\mathrm{x} / 1.96)}, \mathrm{y}=-113.8+1121.6 \mathrm{e}^{(-\mathrm{x} / 2.11)}, \mathrm{y}=-173.1+1582.0 \mathrm{e}^{(-}$ $\mathrm{x} / 2.19)$ for VIF-G $(\mathrm{A}-\mathrm{C}) ; \mathrm{y}=35.5+566.7 \mathrm{e}^{(-\mathrm{x} / 1.13)}, \mathrm{y}=16.4+983.1 \mathrm{e}^{(-\mathrm{x} / 1.38)}, \mathrm{y}=-15.6+1411.5 \mathrm{e}^{(-\mathrm{x} / 1.52)}$ for VIF-WB $(\mathrm{A}-\mathrm{C}) ; \mathrm{y}=$ $-17.7+619.9 \mathrm{e}^{(-\mathrm{x} / 1.19)}, \mathrm{y}=-15.6+1020.2 \mathrm{e}^{(-\mathrm{x} / 1.18)}, \mathrm{y}=-11.3+1416.5 \mathrm{e}^{(-\mathrm{x} / 1.15)}$ for metal $(\mathrm{A}-\mathrm{C}) ; \mathrm{y}=12.7+587.17 \mathrm{e}^{(-\mathrm{x} / 0.53)}, \mathrm{y}=$ $19.8+979.9 \mathrm{e}^{(-\mathrm{x} / 0.65)}, \mathrm{y} 25.6+1374.1 \mathrm{e}^{(-\mathrm{x} / 0.70)}$ for $\operatorname{HDPE}(\mathrm{A}-\mathrm{C})$. All $\mathrm{r}^{2}$ values were $\geq 80 \% ; 1 \mathrm{ppm}=1 \mu \mathrm{L} \cdot \mathrm{L}^{-1}$.

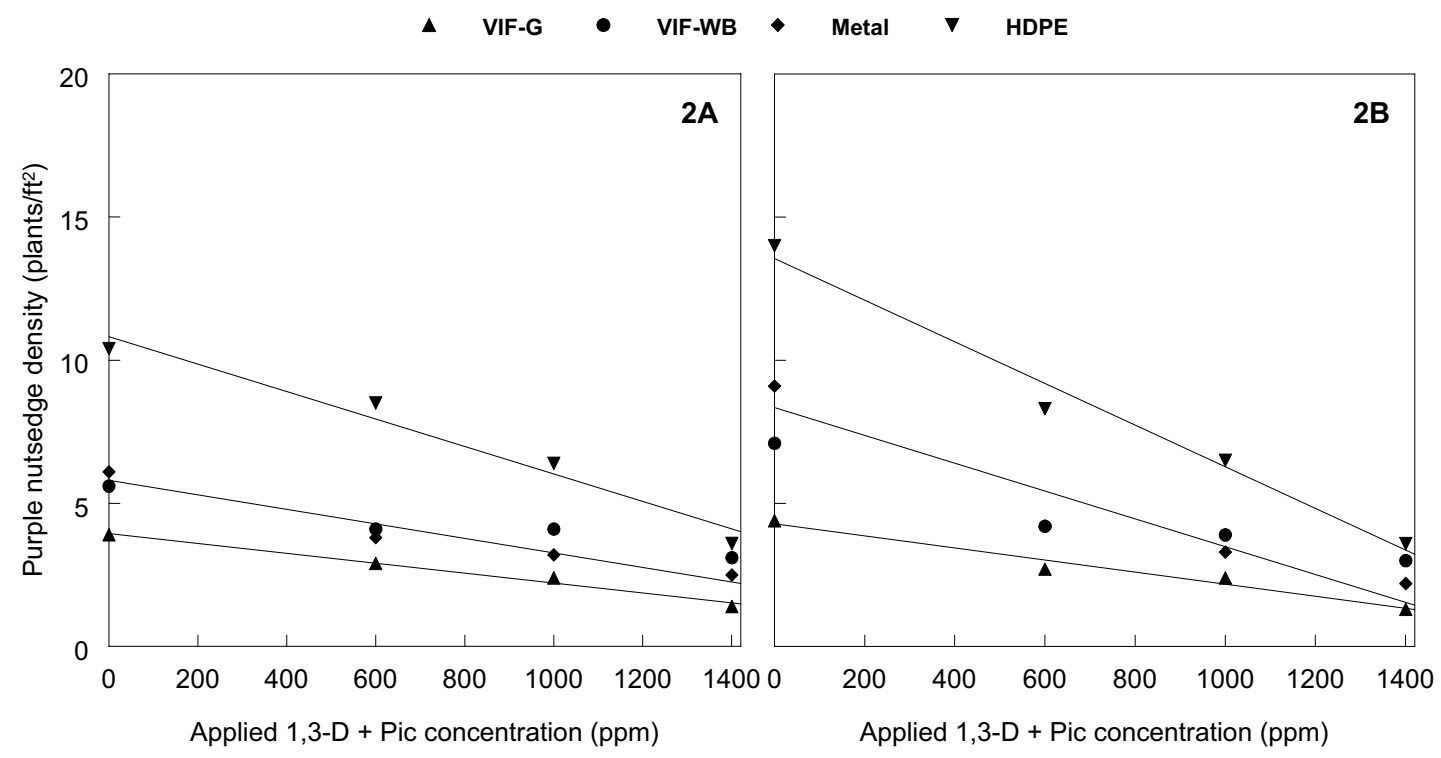

Fig. 2. Effects of applied concentration of 1,3-dichloropropene + chloropicrin (1,3-D + Pic) under different mulch types on purple nutsedge (Cyperus rotundus) densities at (A) 2 and (B) 5 weeks after treatment. Mulch films are green virtually impermeable film (VIF-G), white on black VIF (VIF-WB), metalized (metal), and high-density polyethylene (HDPE) mulches. Regression equations are: $\mathrm{y}=4.12-0.0019 \mathrm{x}, \mathrm{y}=4.44-0.0023 \mathrm{x}$ for $\operatorname{VIF}-\mathrm{G}(\mathrm{A}-\mathrm{B}) ; \mathrm{y}=5.98-0.0024 \mathrm{x}, \mathrm{y}=8.26-0.0047 \mathrm{x}$ for VIF-WB and metal $(A-C) ; y=10.95-0.0048 x, y=13.42-0.0071 x$ for HDPE (A-C). All $r^{2}$ values were $\geq 80 \%$; 1 ppm $=1 \mu \mathrm{L} \cdot \mathrm{L}^{-1}, 1$ plant $/ \mathrm{ft}^{2}=10.7639$ plants $/ \mathrm{m}^{2}$.

applied fumigant concentrations (Fig. 2A-B). At 2 WAT, HDPE mulch had the highest purple nutsedge densities among all films, whereas VIF-G had the lowest populations (Fig. 2A). Both the metalized mulch and VIF-WB had the same purple nutsedge control. In the absence of fumigant, there was a mulch effect on nutsedge emergence through the films, as reflected by the equation intersects, where HDPE mulch had approximately 11 plants $/ \mathrm{ft}^{2}$ in comparison with about 6 and 4 plants $/ \mathrm{ft}^{2}$ for metalized mulch and VIF-WB, and VIF-G, respectively. This effect might be due to the differences in physical properties of the mulches (e.g., color and thickness), which could affect purple nutsedge penetration through the films. Based on the predicted values of the regression lines at 5 WAT, purple nutsedge densities were $\leq 5$ plants $/ \mathrm{ft}^{2}$ with metalized mulch, VIF-WB, and VIF-G with 600 ppm of 1,3-D + Pic, whereas the density was about 8 plants $/ \mathrm{ft}^{2}$ when the soil was covered with HDPE mulch. As the applied 1,3- 
$\mathrm{D}+$ Pic concentration increased, purple nutsedge control under HDPE mulch improved more rapidly than with the other mulches, reaching $<5$ plants $/ \mathrm{ft}^{2}$ with $1400 \mathrm{ppm}$ of the fumigant.

Purple nutsedge densities at 5 WAT declined as fumigant concentrations increased (Fig. 2B). Similar to the nutsedge counts at 2 WAT, the non-fumigated control showed considerable mulch effect on purple nutsedge populations, where VIF-G, and both VIF-WB and metalized mulch had approximately 41 and $67 \%$ less purple nutsedge than HDPE mulch. The treatments covered with VIF-G had purple nutsedge densities $<5$ plants/ $\mathrm{ft}^{2}$, regardless of the applied fumigant concentration, while VIF-WB and metalized mulch reached this nutsedge density with $696 \mathrm{ppm}$ of $1,3-\mathrm{D}+$ Pic. In contrast, $1186 \mathrm{ppm}$ of $1,3-\mathrm{D}+$ Pic were needed to reach this weed density under HDPE mulch.

Under the conditions of this study, correlation analysis showed that fumigant retention readings at $3 \mathrm{DAT}$ are effective indicators for predicting purple nutsedge densities at 5 WAT $(r \leq-0.94)$. Coefficients were -0.94 , $-0.97,-0.97$, and -0.99 for VIFG, VIF-WB, metalized, and HDPE mulches, respectively, suggesting that both variables are closely associated at least $94 \%$ of the time, with purple nutsedge densities declining as 1,3-D + Pic retention increased. These findings conclusively proved that $1,3-\mathrm{D}$ + Pic activity on purple nutsedge can be enhanced with the use of more retentive films, which cause longer fumigant retention, thus improving efficacy. Moreover, application of 1400 ppm of 1,3-D + Pic, in conjunction with high-retention mulches, suppress purple nutsedge densities below 5 plants $/ \mathrm{ft}^{2}$. Stall and Morales-Payan (2006) determined that a marketable yield loss of $10 \%$ can occur with season-long purple nutsedge interference with the population of 2.3 plants $/ \mathrm{ft}^{2}$.
Furthermore, growers that elect to use this alternative might compensate for the relatively higher cost of VIF and metalized mulches in comparison with HDPE mulch by reducing the 1,3-D + Pic application rate, without losing herbicidal activity.

\section{Literature cited}

Desaeger, J.A.J., J.E. Eger, Jr., A.S. Csinos, J.P. Gilreath, S.M. Olson, and T.M. Webster. 2004. Movement and biological activity of drip-applied 1,3-dichloropropene and chloropicrin in raised mulched beds in the southeastern USA. Pesticide Mgt. Sci. 60:1220-1230.

Dow AgroSciences. 2006. InLine soil fungicide and nematicide. 17 July 2006. <http://www.cdms.net/ldat/ld50U001. pdf>.

Gastec Corp. 2003. Environmental analysis technology handbook. 4th ed. Gastec Corp., Ayase-city, Japan.

Gilreath, J.P. and B.M. Santos. 2004a. Herbicide dose and incorporation depth in combination with 1,3-dichloropropene plus chloropicrin for purple nutsedge control in tomato and pepper. Crop Protection 23:205-210.

Gilreath, J.P. and B.M. Santos. 2004b. Manejo del coquillo (Cyperus rotundus) con alternativas al bromuro de metilo en tomate de mesa. Manejo Integrado de Plagas y Agroecología 71:54-58.

Gilreath, J.P., B.M. Santos, and T.N. Motis. 2003. Length of irrigation and soil humidity as basis for delivering fumigants through drip lines in Florida spodosols. Proc. Fla. State Hort. Soc. 116:85-87.

Gilreath, J.P., T.N. Motis, and B.M. Santos. 2005. Cyperus spp. control with reduced methyl bromide plus chloropicrin rates under virtually impermeable films in pepper. Crop Protection 24:285-287.

Minuto, A., A. Gilardi, M.L. Gullino, and A. Garibaldi. 1999. Reduced dosages of methyl bromide applied under gasimpermeable plastic films for controlling soilborne pathogens of vegetable crops. Crop Protection 18:365-371.
Morales-Payan, J.P., B.M. Santos, W.M. Stall, and T.A. Bewick. 1997. Effects of purple nutsedge (Cyperus rotundus) on tomato (Lycopersicon esculentum) and bell pepper (Capsicum annumm) vegetative dry matter and fruit yield. Weed Technol. 11:672-676.

Motis, T.N., S.J. Locascio, J.P. Gilreath, and W.M. Stall. 2003. Season-long interference of yellow nutsedge (Cyperus rotundus) with polyethylene-mulched bell pepper (Capsicum annuum). Weed Technol. 17:543-549.

Santos, B.M., J.P. Gilreath, and T.N. Motis. 2005. Managing nutsedge and sting nematode with reduced methyl bromide plus chloropicrin rates under virtually impermeable films in pepper. Hort Technology 15:596-599.

SAS Institute. 2000. SAS/Stat user's guide. Version 8.1. SAS Inst. Inc., Cary, N.C.

Stall, W.M. and J.P. Gilreath. 2002. Weed control in tomato, p. 55-58. In: W.M. Stall (ed.). Weed management in Florida fruits and vegetables, 2002-2003. Inst. Food Agr. Sci. Publ., Univ. of Florida, Gainesville.

Stall, W.M. and J.P. Morales-Payan. 2006. The critical period of nutsedge interference in tomato. 17 July 2006. <http://swfrec. ifas.ufl.edu/LIV/groups/IPM/weed_ con/nutsedge.htm>.

U.S. Department of Agriculture. 2005. Statistics of vegetables and melons. 14 Feb. 2006. <http://www.usda.gov/nass/ pubs/agr05/05_ch4.PDF>.

U.S. Environmental Protection Agency. 1999. Protection of stratospheric ozone: Incorporation of Montreal Protocol adjustment for a 1999 interim reduction in Class I, Group VI controlled substances. Federal Register 64:29240-29245.

Watson, R.T., D.T. Albritton, S.O. Anderson, and S. Lee-Bapty. 1992. Methyl bromide: Its atmospheric science, technology and economics. Montreal Protocol Assessment Suppl. United Nations Environ. Prog. Nairobi, Kenya. 